DOI 10.37279/2309-7663-2020-6-2-254-264

УДК 911.6

T. V. Ashikhmina,

T. V. Ovchinnikova,

P. S. Kuprienko,

A. M. Ashikhmin

\section{Geoecological features of solid municipal waste storage facilities placement in Voronezh region}

Voronezh State Technical University, Voronezh, Russian Federation

e-mail:tv6234@yandex.ru

Abstract The article discusses the geo-environmental conditions of Voronezh region, which have a significant impact on potential environmental threat of solid municipal waste (MSW) facilities. Zoning of the region was carried out according to the priority of potentially dangerous geoecological factors to be assessed when choosing the location of MSW landfills. Conclusions made in this work can serve as recommendations in formation of a resource-saving environmentally friendly waste management system in the territory of the Voronezh region.

Keywords geo-ecological conditions, solid municipal waste landfills, natural landscape zoning, environmental monitoring, Voronezh region.

\title{
Introduction
}

In the modern world there are a significant number of diverse environmental problems. One of the most urgent is the problem of solid municipal waste management (MSW).

Despite development of processing and incineration technologies, the basic procedure to handle municipal waste remains to be disposed of at landfills that occupy large areas and have a long-term negative impact on the environment. In this regard, the planning of the territorial distribution of such facilities should be carried out not without information about complex of climatic and geoecological factors of the region.

Currently, $321 \mathrm{MSW}$ facilities (landfills, authorized and unauthorized landfills) with a total area of 568. 16 hectares are operating in the Voronezh region. 17 licensed municipal solid waste landfills are located in 15 municipalities and occupy 184. 3 hectares of land (Fig. 1). About 1038 thousand tons of waste are disposed on them, mainly without preliminary sorting $[1,2]$.

On the territory of 19 municipalities that do not have MSW facilities included in the SRWDF (State register of waste disposal facilities), waste is disposed of in authorized and unauthorized landfills, or taken out of the municipalities where it was generated.

Location of MSW landfills based on their binding to large sources of waste generation. Most of these facilities are concentrated in the western part of the Voronezh region.

This study is concluded in order to regionalize territory of the Voronezh region on the basis of the analysis of geoecological factors that significantly affect the environmental safety of MSW landfills, as well as develop recommendations on priority areas for assessing the conditions of disposal and environmental monitoring of waste storage facilities. 


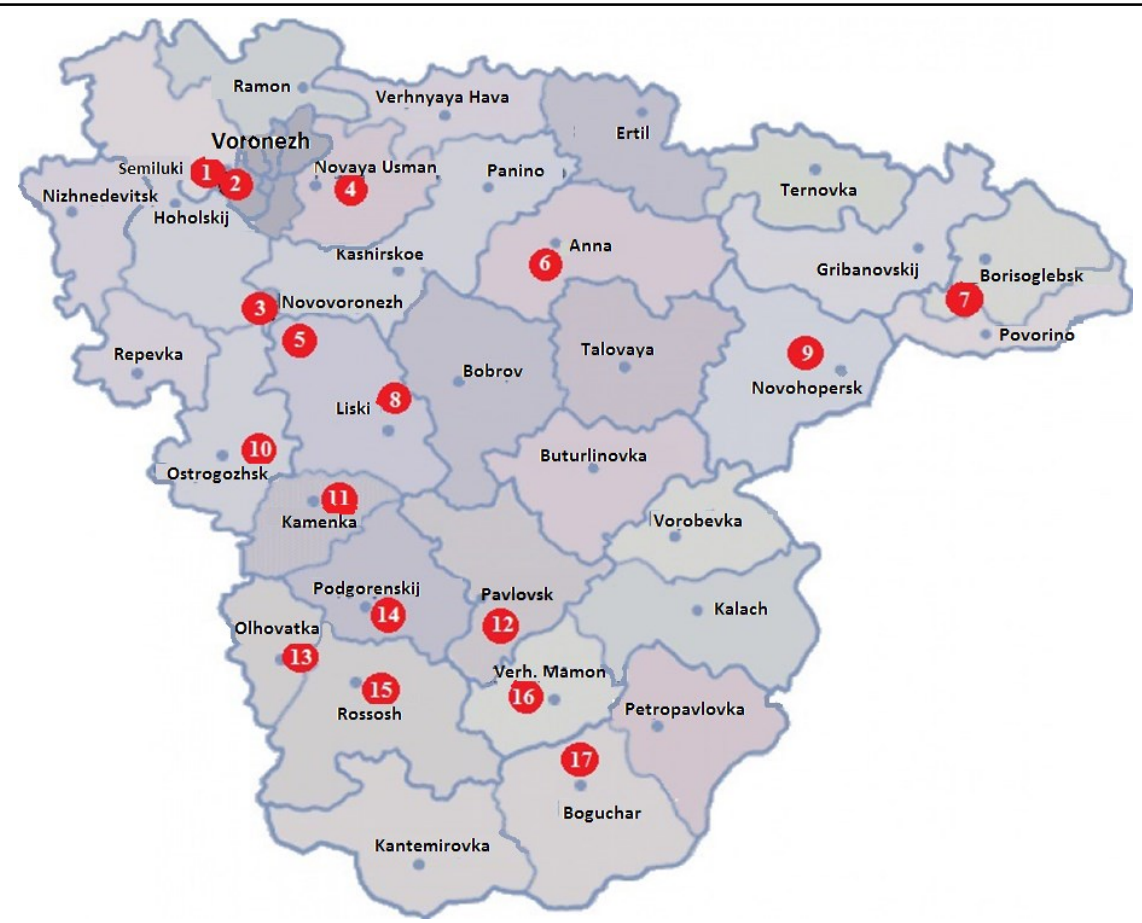

Fig. 1. MSW landfills in municipal areas of the Voronezh region

MSW landfills: 1 - LLC "Cascade" Semiluksky district; 2 - LLC EcoSphere Semiluksky district (LLC Voronezh-MSW); 3 - municipal unitary enterprise Novovoronezh "Aquaservice", Novovoronezh; 4 - LLC Poetro-Polygon, New Usman river; 5 - Municipal Unitary Enterprise "Davydovskoye Municipal Economy" of the Liskinsky District; 6 - LLC Polygon, urban settlement Anna; 7 - LLC "Improvement", Borisoglebsk; 8-LLC "MUP for cleaning the city", Liski; 9 - LLC "Heating system plus", Novokhopersky district; 10 - Municipal Unitary Enterprise "Ostrogozhsky Plant for Improvement", Ostrogozhsk; 11 - LLC "Resource MSW", Kamensky district, s. Evdakovo; 12 - Pavlovsk municipal unitary enterprise housing and communal services, Pavlovsk; 13 - IP Lunev A. I., Olkhovatsky district; 14 - LLC "Podgorensky municipal center", Podgorensky district; 15 - municipal unitary enterprise of Rossosh city, special vehicle base "Kommunalnik"; 16 - LLC "Zhilservice", Verkhnemamonsky district, Upper Mamon; 17 - LLC Bogucharbytservice, Bogucharsky district, Boguchar.

Composed by the autors

\section{Object and research methods}

The object of the study is the geoecological conditions and processes that determine the natural landscape conditions of the territories where the existing and planned MSW landfill sites are planned.

During the research, were used materials from the SRWDF and the waste cadastre of the Voronezh region $[1,2]$, the Voronezh center for hydrometeorology and environmental monitoring [3], and the Territorial center for state monitoring of the geological environment and water bodies of the Voronezh region [4]. Analysis of the natural conditions of Voronezh region was carried out on the basis of the results of F. N. Milkova, V. B. Mikhno, B. P. Akhtyrtseva, V. M. Smolyaninova, et al. [5-8].

Studies were conducted using methods: analysis and synthesis, expert judgment, cartographic, statistical, comparative geographic, geographic information mapping, analysis of literary sources. 


\section{Results and discussion}

The waste transformation processes at landfills, accompanied by the emission of generated substances into the environment, allow us to consider these objects as naturaltechnical geo-ecological systems that are in constant long-term interaction with the region's ecogeosphere. The directions and consequences of this interaction depend significantly on the geoecological conditions of the polygon location, primarily on the geological structure of the territory. Moreover, the water permeability of the reliefforming rocks, their structure and mineralogical composition, as factors determining the development of exogenous processes are of great importance [9].

Analysis of the natural landscape conditions of Voronezh region allowed us to identify 6 districts with different conditions for the placement of MSW landfills (Fig. 2, Table 1).

The territory of the northwestern region has a flat character and varying degrees of dissection. The location of the district is the Central Russian Upland. The watersheds are often flat. River valleys are usually narrow and deeply incised; floodplains and floodplain terraces are poorly developed due to the high density of karst Upper Devonian limestones prevailing here. Such a geological structure requires additional measures to protect the base of the landfill from destruction.

The dense ravine-girder network, which arose due to water erosion, also complicates the construction of waste disposal facilities. The width of specific beams is small - 15-50 m, they are mainly canyon-shaped. Among the soils, gray forest and podzolized chernozems predominate. In this region, the maximum amount of precipitation falls for the region, which leads to increased accumulation of leachate.

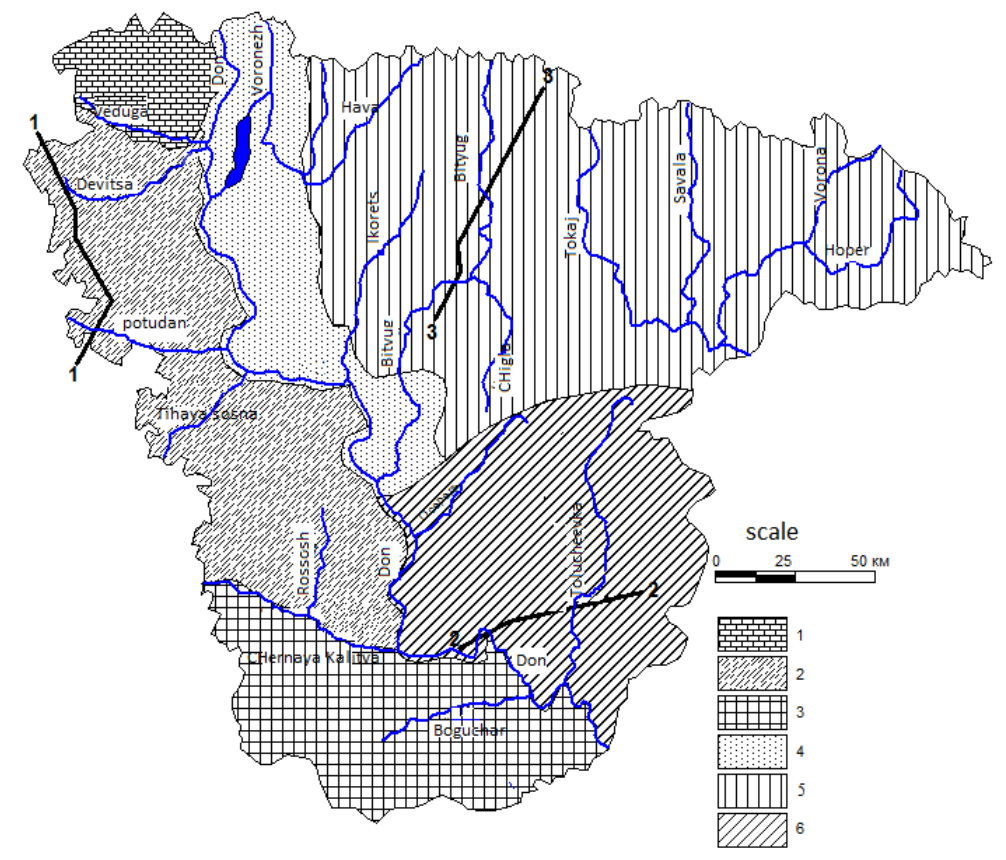

Fig. 2. Natural-landscape zones of the Voronezh region

1 - Northwest region; 2 - Western region; 3 - Southern region; 4 - Central district; 5 Northeast region; 6 - Southeast region;

Composed by the autors

1-1, 2-2, 3-3 location of geological sections (Fig. 3, 4, 5) 
Table 1

Characterization of districts according to conditions of construction and operation of MSW landfills in the Voronezh region

\begin{tabular}{|c|c|c|c|c|c|}
\hline$\stackrel{\mathscr{0}}{\stackrel{0}{0}}$ & Relief Forming Rocks & $\begin{array}{l}\text { Hydro } \\
\text { ther- } \\
\text { mal } \\
\text { coeffi- } \\
\text { cient }\end{array}$ & $\begin{array}{l}\text { Water } \\
\text { permeability of } \\
\text { rocks, \% atm. } \\
\text { precipitation }\end{array}$ & $\begin{array}{l}\text { Valley- } \\
\text { beam } \\
\text { section } \\
\mathrm{km} / \mathrm{km}^{2}\end{array}$ & $\begin{array}{l}\text { Beam } \\
\text { area, } \\
\mathrm{km}^{2}\end{array}$ \\
\hline 1 & 2 & 3 & 4 & 5 & 6 \\
\hline 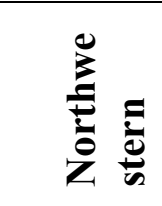 & $\begin{array}{ll}\text { Upper } & \text { Devonian } \\
\text { Limestones } & \end{array}$ & 1,1 & 9,0 & 1,2 & 110,4 \\
\hline$\frac{5}{5}$ & $\begin{array}{l}\text { Sands and clays of the } \\
\text { Paleogene; } \\
\text { Cretaceous } \\
\text { rocks }\end{array}$ & 1,0 & 8,0 & 1,5 & 792,0 \\
\hline 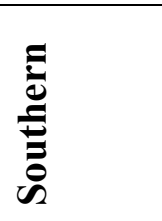 & $\begin{array}{l}\text { Chalks and marls of the } \\
\text { Upper Cretaceous }\end{array}$ & 0,9 & 7,7 & 0,9 & $\begin{array}{c}1008, \\
0\end{array}$ \\
\hline ن & $\begin{array}{l}\text { Quaternary Ancient } \\
\text { Alluvial Sands }\end{array}$ & 1,0 & 7,8 & 0,5 & 62,5 \\
\hline$\frac{1}{\frac{1}{0}}$ & Quaternary Glacial Loam & 0,7 & 2,4 & 0,5 & 625,0 \\
\hline 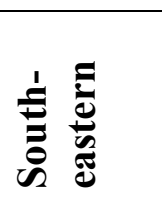 & $\begin{array}{l}\text { Glacial loam; sands and } \\
\text { clays of paleogene; } \\
\text { Cretaceous of the Upper } \\
\text { Cretaceous }\end{array}$ & 0,8 & 7,7 & 1,2 & 513,6 \\
\hline
\end{tabular}

Composed by the autors

The western region is also located on the Central Russian Upland. Among the relief-forming rocks, sands, clays, and loams of Paleogene, Cretaceous, and Upper Cretaceous marls predominate (Fig. 3).

The presence of carbonate rocks among the relief-forming species requires additional protection of the base of the landfill. The area has a relatively dense hydrographic network. The river valleys have significant incisions and a width of up to $2 \mathrm{~km}$, they are well developed and slightly asymmetric. The main basis of erosion for the area is river Don, which leads to a very high dissection of the relief by ravines and beams. 
In the north of the district - in the river Maiden, where sands of Cenomanian and Albian age lie close to the surface, the beams are deep, their width is on average 40$50 \mathrm{~m}$. The beams along the Potudan and Tikhaya Sosna rivers formed in Cretaceous rocks have a short length and a circus shape. In the south of the district, the beams are well formed, with a wide bottom. In addition to fluvial processes, Cretaceous karst is active. Leached chernozems, typical and ordinary, are prevalent in the region.

The southern region is also located on the Central Russian Upland. The relief of the area is a strongly dissected wavy plain. Often there are remnant watersheds composed of paleogene rocks. River valleys are relatively wide.

The density of the beam network in the region on average is $0.9 \mathrm{~km} / \mathrm{km}^{2}$, rarely up to $1.2 \mathrm{~km} / \mathrm{km}^{2}$. The density of ravines is up to $1.4 \mathrm{~km} / \mathrm{km} 2$. Beams are usually wide, with a bottom of up to 100-200 m, numerous landslides on the slopes. Permanent watercourses formed due to drainage of the upper aquifer are found in the lower reaches of the beams. Among the relief-forming rocks, water-permeable shallow-marl rocks of the Upper Cretaceous prevail here (Fig. 4).

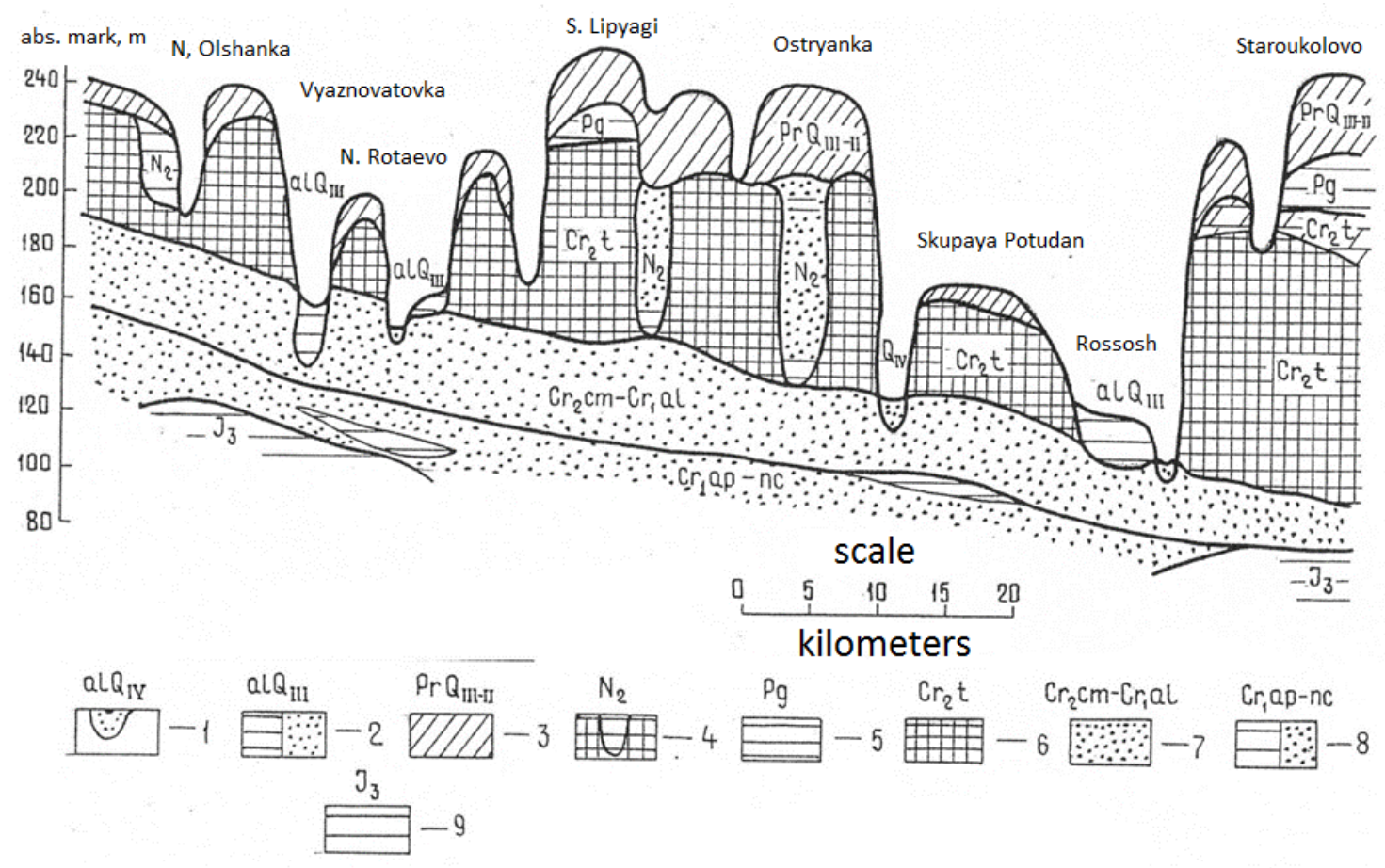

Fig. 3. Geological section along the line 1-1

Deposits: 1 - Quaternary alluvial sands and clays; 2 - Quaternary ancient alluvial sands and clays; 3 -Quaternary deluvial and glacial loams; 4 -Neogene deposits in karst-clays and sands; 5 - paleogene clays; 6 - Upper Cretaceous Cretaceous deposits of the Turonian stage; 7 - Upper Lower Cretaceous Cenomanian-Albian sands; 8 - Lower Cretaceous AptNeocomian clays and sands; 9 - Upper Jurassic clays

Composed by the autors 


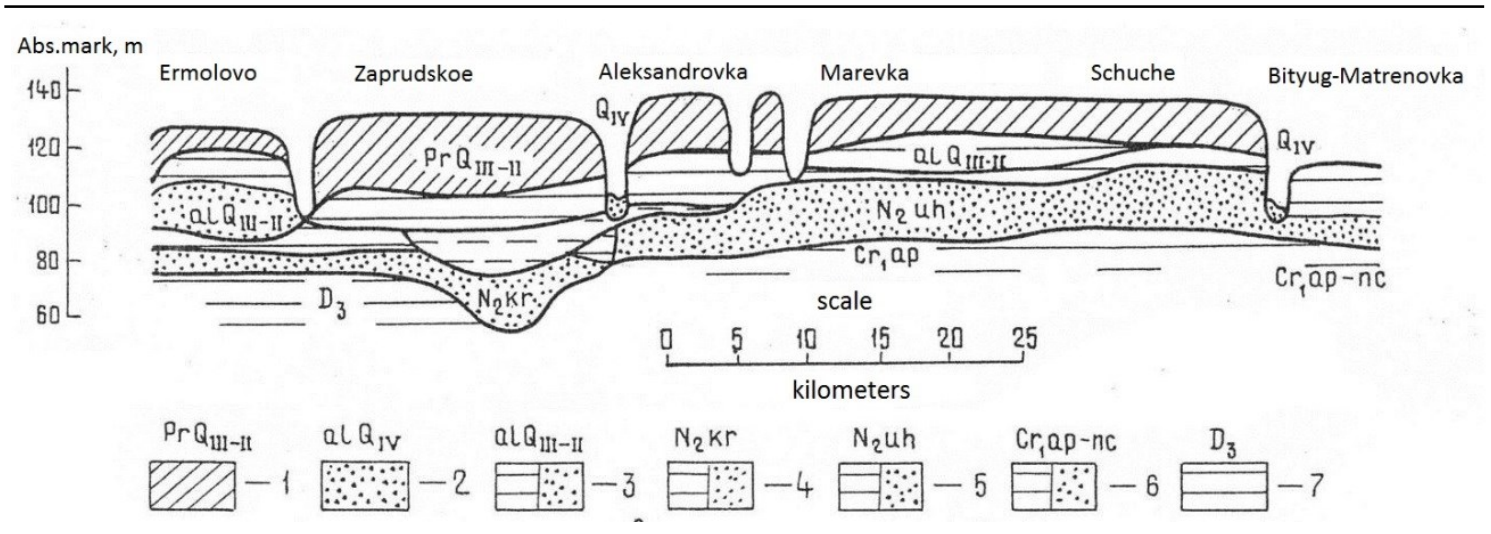

Fig. 4. Geological section along the line 2-2

Deposits: 1 -Quaternary alluvial sands and clays; 2 - Quaternary ancient alluvial sands and clays; 3 -Quaternary loams; 4 - paleogene clays; 5 - Upper Cretaceous Santonian marls; 6-Upper Cretaceous Turonian Cretaceous; 7 -Lower Cretaceous Cenomanian-Albian sands; 8 - Middle Carboniferous Verea clays and sands; 9 - Lower Carboniferous Ozersko-Khovans limestones, clays and sands; 10 - Middle Upper Devonian clays and sandstones

Composed by the autors

On the watersheds, these rocks are covered by Paleogene deposits - glauconite sands, clays. Among Quaternary sediments clay loam mantle of eluvial origin are common; deluvial loams are developed along the slopes of the beams. Just like the previous ones, this area is characterized by a considerable density of ravine-girder network and the development of karst. Among the soils, chernozems predominate ordinary, southern, leached. The annual precipitation is relatively small, which reduces the amount of filtrate formed at the landfills.

A significant part of the central region is occupied by the river valleys of the Don and Voronezh with large floodplains and terraces composed of ancient alluvial sands of the Quaternary age. The width of the river valleys is 3-6 km, the density of the beam network is not more than $0.5-0.6 \mathrm{~km} / \mathrm{km}^{2}$. Gullies distributed rarely, their density is up to $0.3 \mathrm{~km} / \mathrm{km}^{2}$. In addition to ravines and gullies, there are sandy mounds of aeolian and water-accumulative origin, as well as basins, traces of ancient river channels. Although loamy rocks are attached to the sands in the geological structure in the eastern part of the region, generally well-permeable rocks predominate, which requires increased protection of the base and walls of the landfill from penetration of the filtrate, which will inevitably lead to pollution of groundwater. The area is well humidified and has a humidification coefficient of 1.04 . The soils are represented mainly by leached chernozems - typical, ordinary.

The northeastern region is confined to the Oka-Don lowland with flat watersheds, a weakly incised ravine-gully (less than $0.5 \mathrm{~km} / \mathrm{km}^{2}$ ) network and fairly wide, welldeveloped river valleys. Absolute elevations of the watersheds are up to $170 \mathrm{~m}$. A gentle relief favors the construction of landfills, and among the relief-forming rocks glacial Quaternary loams with a thickness of more than $20 \mathrm{~m}$ prevail, which well protect groundwater from the filtrate from them (Fig. 5). The region is dominated by chernozems and meadow chernozem soils.

In the Northeast region, the region has the lowest rainfall infiltration rates to the groundwater level of $2.4 \%$. At the same time, in many parts of the area close to the surface there is a water rush, waterlogging of lands and suffusion are observed. In the 
spring, the overhead connects to surface waters and can be contaminated with leachate from landfills. Therefore, it is important in this area to protect accumulated waste from contact with snowmelt. For this, it is possible to recommend the construction of protective shafts around the landfill. When placing the landfill, waterlogged areas and suffusion saucers should be avoided.

The suitability of beams for the construction of landfills depends on the composition of the relief-forming rocks: in river valleys, where dense glacial loams are eroded, the beams have a considerable width and gentle slopes composed of loose rocks. There are also beams formed in glacial loams, their width is smaller, they have outlets of groundwater. If there are no underground water outlets in the beam, then the MSW landfill can also be located in it.

The southeastern region is located on the Kalach Upland. Among the reliefforming rocks, glacial loams, sands and clays of the Paleogene, chalk of the Turonian layer and marl of Santon dominate. The elevation is significant, the ravine-beam network is dense. The Kalach Upland is a plain strongly divided by ravines and gullies. The rivers have a high floodplain with a deeply embedded channel and left-bank terraces up to a kilometer wide. The average density of the beam network is $1.2 \mathrm{~km} / \mathrm{km}^{2}$, (ravine up to $2 \mathrm{~km} / \mathrm{km}^{2}$ ). Beams are mainly short, with steep slopes. The watersheds, as in the Southern region, are often remnants, in this case arising from karst processes occurring simultaneously with the fluvial ones. Among the soils, leached chernozems, typical, ordinary, are common. The most favorable conditions for the placement of landfills are on the watersheds of the area, where Paleogene clays act like a protective screen. A small annual amount of precipitation in the area contributes to a reduced formation of leachate at landfills.

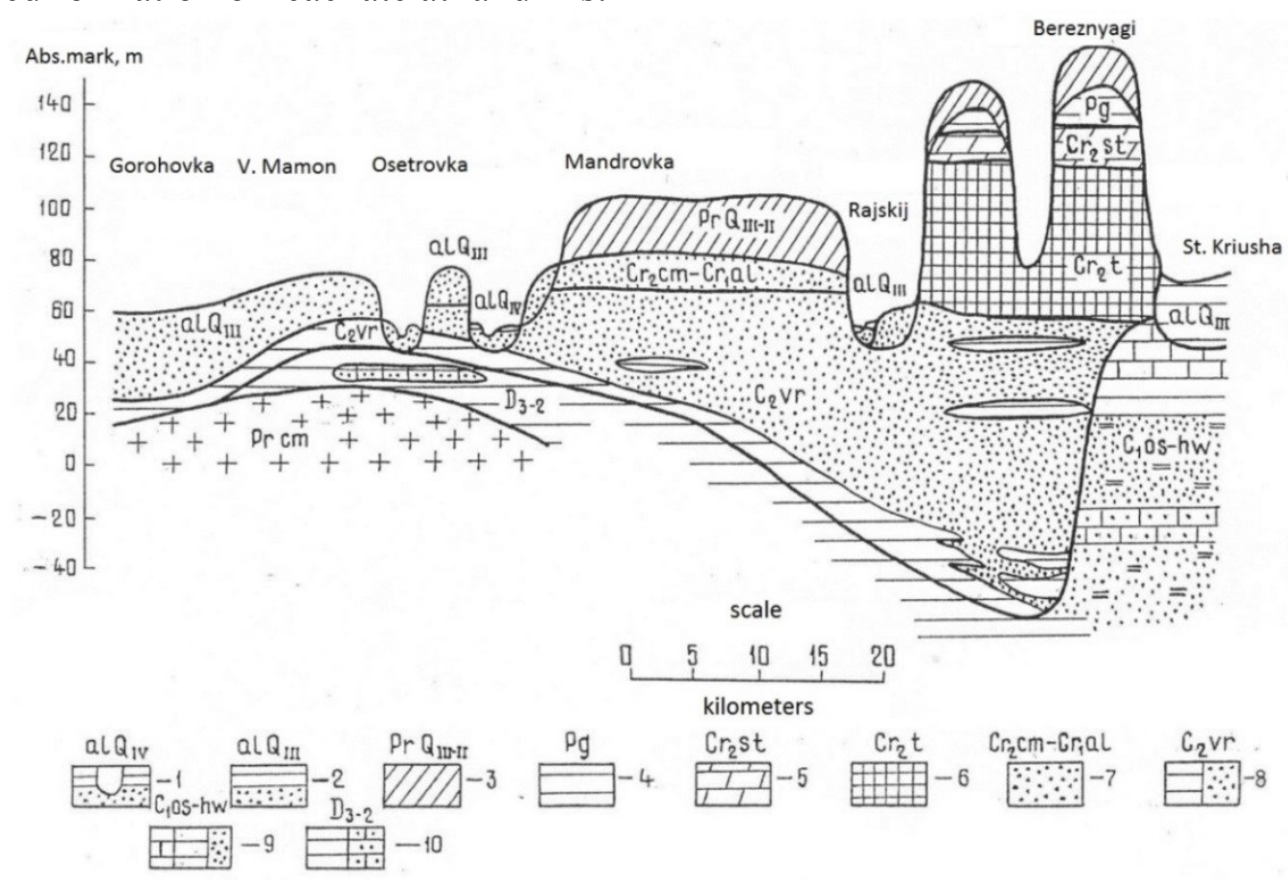

Fig. 5. Geological section along the line 3-3.

Deposits: 1 - Quaternary integumentary loams; 2 - Quaternary alluvial sands and clays; 3 - Quaternary ancient alluvial sands and clays; 4 - Neogene sands and clays of the Krivoborsky suite; 5 - Neogene sands and clays of the Ottoman Formation; 6 - Lower Cretaceous sands and clays of apt-neocom; 7 - Upper Devonian clays

Composed by the autors 
In general, between the selected areas there is a significant similarity of climate. The main differences in relief are observed between the Northeast and other areas. According to the peculiarities of the geological structure, significant similarities are observed between the Western, Southern and Southeastern regions located on the Central Russian and Kalach Uplands, which differ significantly from the Central and Northeast regions.

The territorial distribution of MSW landfills, taking into account the natural landscape zoning in the Voronezh region, is presented in Fig. 6.

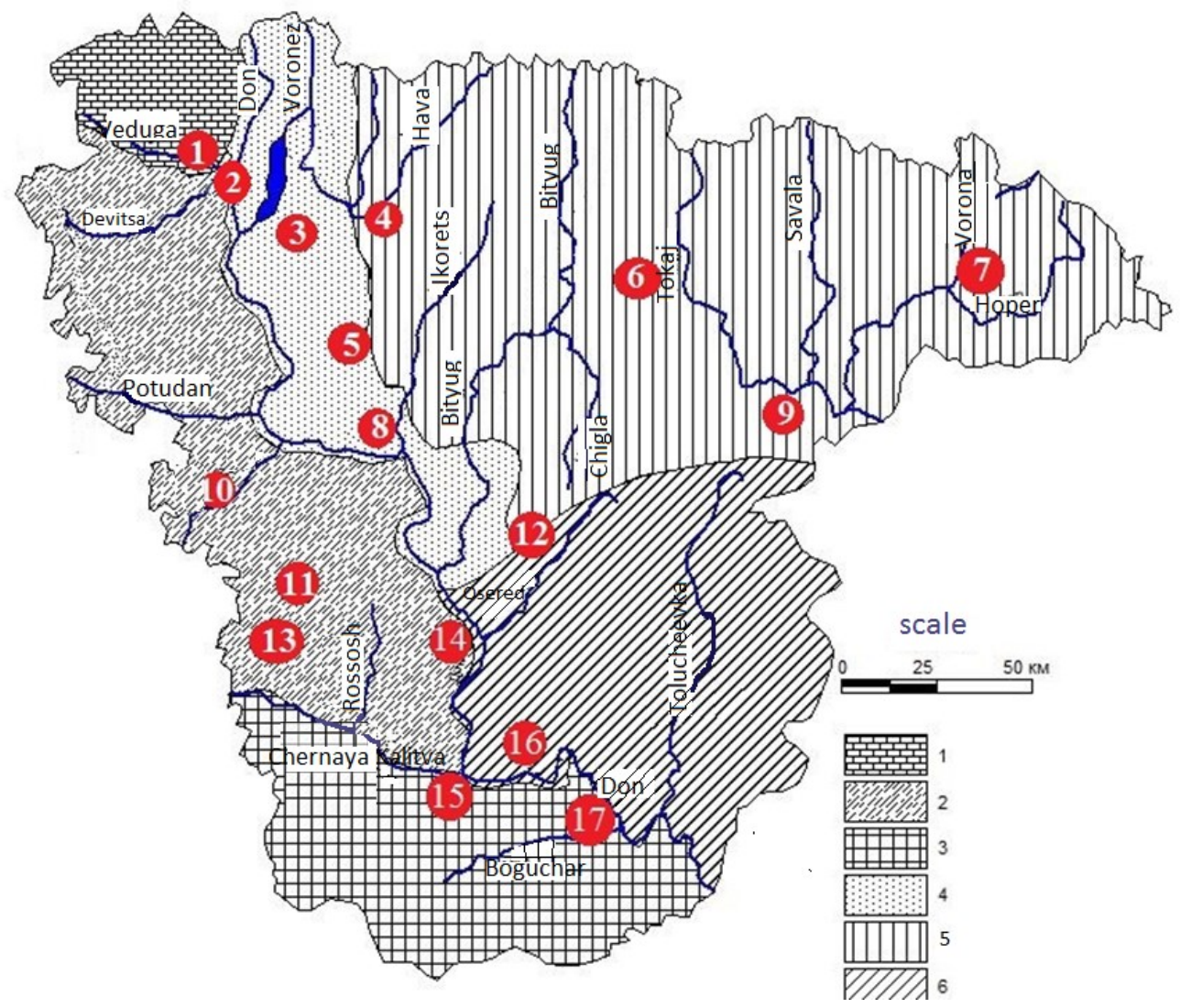

Fig. 6. Location of MSW landfills in selected natural landscape areas of the Voronezh region

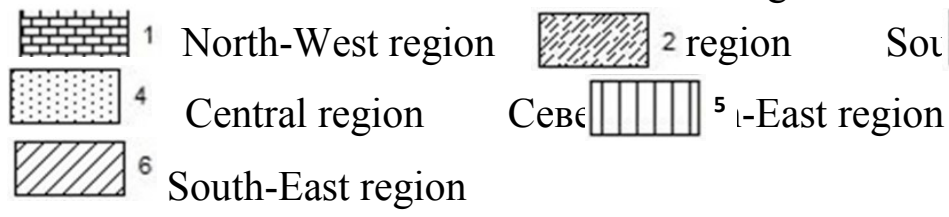

\section{Composed by the autors}

The tendency for the placement of MSW landfills on the territory of the Voronezh region suggests an increase in their number in geoecologically unfavorable areas of the Voronezh region. 


\section{Conclusions}

Most of the landfills are located within the central and western geo-ecological regions. The underlying rocks of these territories are characterized by the predominance of sand and chalk deposits. Landfill construction in these areas should include mandatory and priority measures to protect underlying rocks and groundwater from leachate infiltration. Planning for the location of long-term waste storage facilities should take into account the likelihood of karst processes.

The most suitable for the construction of polygons relief-forming rocks have a northeast natural landscape region. Groundwater is protected here by loamy and clayey rocks, however, there is a risk of waterlogging of the land and the development of suffusion processes, which must be taken into account first of all when choosing the location of the MSW landfill and taking appropriate environmental measures at the operating facilities.

An environmental monitoring system in the landfill sites should be built taking into account the natural landscape zoning and the priority of potentially dangerous geoecological conditions.

So, in areas with unprotected groundwaters (western and central regions), the priority direction of monitoring is monitoring the status of groundwater, as well as the processes of filtrate penetration into groundwater. In the eastern regions, the priority direction of monitoring should be the control of territory pollution by the surface runoff of the landfill. Monitoring the state of atmospheric air at the landfill and within its sanitary protection zone is especially necessary in the northwestern and western regions in connection with the movement of a large volume of air masses in the direction of densely populated areas.

The results of the studies are recommended for use to optimize territorial planning and environmental policy in the processes of forming a resource-saving waste management system in the territory of the Voronezh region.

\section{Literature}

1. The state register of waste disposal facilities in the territory of the Voronezh region. URL: https://uoit. fsrpn. ru/groro?search= Voronezh\%20region - date of access: 15. 01. 2020.

2. Regional waste inventory of the Voronezh region. URL: http://36. rpn. gov. ru/node/856 - date of access: 07.02.2020.

3. The site of the Voronezh Center for Hydrometeorology and Environmental Monitoring. URL: http://www. meteorf. ru/about/structure/cgms/3175/ - date of access: 20.02.2020.

4. The site of the Territorial Center for State Monitoring of the Geological Environment and Water Objects of the Voronezh Region "VoronezhGeomonitoring", a branch of JSC "Geocenter-Moscow" URL: http://centralpgo. rosgeo. com/en/\# - date of access: 21. 02. 2020.

5. Smolyaninov V. M. Underground waters of the Central Black Earth region: conditions for their formation, use: monograph / V. M. Smolyaninov. Voronezh: Sources, 2003. 250 p. 
6. Milkov F. N. Kalach Upland (Experience of landscape-typological characteristics) / F. N. Milkov, N. I. Akhtyrtseva, B. P. Akhtyrtsev / Voronezh. state un-t Voronezh, 1972. $180 \mathrm{p}$.

7. Milkov F. N. Geography of the Voronezh region / F. N. Milkov, V. B. Mikhno, Yu. V. Porosenkov. Voronezh, 1994130 p.

8. Ovchinnikova T. V., Kosinova I. I., Smolyaninov V. M., Galkin A. N., Ashikhmina T. V. Ecological and geodynamic characteristics of the territory of the Central Black Earth region // Bulletin of Voronezh State University. Series: Geology. 2019. No 3., P. 104-110

9. Smolyaninov V. M., Ovchinnikova T. V. Geographic approaches in land management planning in regions with intensive development of natural and technological emergencies: monograph / V. M. Smolyaninov, T. V. Ovchinnikov. Voronezh: publishing house "Sources", 2010. 230 p.

\section{Т. В. Ашихмина, П. С. Куприенко, Т. В. Овчинникова, А. М. Ашихмин}

Геоэкологические особенности размещения объектов хранения твердых коммунальных отходов на территории Воронежской области ФГБОУ ВО «Воронежский государственный технический университет», Российская Федерация, г. Воронеж, Российская Федерация e-mail:tv6234@yandex.ru

Аннотация В статье рассматриваются геоэкологические условия Воронежской области, оказывающие существенное влияние на экологическую безопасность объектов размещения твердых коммунальных отходов (ТКО). Проведено районирование территории региона по приоритетности потенциально опасных геоэкологических факторов, подлежащих оченке при выборе мест размещения полигонов ТКО. Выводы, сделанные в работе, могут служить рекомендащиями при формировании ресурсосберегающей экобезопасной системы обращения с отходами на территории Воронежской области.

Ключевые слова геоэкологические условия, полигоны твердых коммунальных отходов, природно-ландшафтное районирование, экологический мониторинг, Воронежская область.

\section{Литература}

1. Государственный реестр объектов размещения отходов на территории Воронежской области. [Электронный ресурс]. Режим доступа: https://uoit. fsrpn. ru/groro?search=воронежская\%20область - дата обращения: 15. 01. 2020.

2. Региональный кадастр отходов Воронежской области. [Электронный ресурс]. Режим доступа: http://36. rpn. gov. ru/node/856 - дата обращения: 07.02.2020.

3. Сайт Воронежского центра по гидрометеорологии и мониторингу окружающей среды. [Электронный ресурс]. Режим доступа: 
http://www. meteorf. ru/about/structure/cgms/3175/ _ _ дата обращения: 20. 02. 2020.

4. Сайт Территориального центра государственного мониторинга геологической среды и водных объектов Воронежской области «Воронеж-Геомониторинг», филиал АО «Геоцентр-Москва» [Электронный ресурс]. Режим доступа: http://centralpgo. rosgeo. com/ru/\# - дата обращения: 21.02.2020.

5. Смольянинов В. М. Подземные воды Центрально-Черноземного региона: условия их формирования, использование: монография / В. М. Смольянинов. Воронеж: Истоки, 2003. 250 с.

6. Мильков Ф. Н. Калачская возвышенность (Опыт ландшафтно-типологической характеристики) / Ф. Н. Мильков, Н. И. Ахтырцева, Б. П. Ахтырцев, Воронеж. гос. ун-т., Воронеж, 1972. 180 с.

7. Мильков Ф. Н. География Воронежской области / Ф. Н. Мильков, В. Б. Михно, Ю. В. Поросенков. Воронеж, 1994. 130 с.

8. Овчинникова Т. В., Косинова И. И., Смольянинов В. М., Галкин А. Н., Ашихмина Т. В. Эколого-геодинамическая характеристика территории Центрально-Черноземного региона // Вестник ВГУ. Серия: Геология. 2019. № 3., С. 104-110.

9. Смольянинов В.М., Овчинникова Т. В. Географические подходы при землеустроительном проектировании в регионах с интенсивным развитием природных и техногенных чрезвычайных ситуаций: монография/ В. М. Смольянинов, Т. В. Овчинникова. Воронеж: изд-во «Истоки», 2010. 230 с

Поступила в редакциюю 12.06.2020 2. 